\title{
The biophysical perspective of a middle income economy: Material Flows in Mexico
}

\author{
Ana Citlalic Gonzalez-Martinez $z^{\mathrm{i}, *}$, Heinz Schandli \\ 'Department of Economics and Economic History and Institute for Environmental \\ Science and Technology \\ Autonomous University of Barcelona, Spain \\ Edifici B-Campus \\ 08193 Bellaterra (Cerdanyola del Vallès) \\ Barcelona, Spain \\ Ph:+(34) 935814104 \\ Fax: +(34) 935813331 \\ anacitlalic.gonzalez@uab.es \\ iiCSIRO Sustainable Ecosystems, Canberra, Australia, \\ GPO Box 284, Canberra ACT 2601. Australia \\ Ph: +61 (0) 262421673 \\ heinz.schandl@csiro.au \\ ${ }^{*}$ Corresponding author
}

Accepted for publication in Ecological Economics (19/12/2007) pending revision in response to the referees. The amended and re-submitted version is included here.

\begin{abstract}
We analyse natural resource use dynamics in the Mexican economy during the last three decades. Despite low and uneven economic growth, the extraction and use of materials in the Mexican economy has continuously increased during the last 30 years. In this period, population growth rather than economic growth was the main driving force for biophysical growth. In addition, fundamental changes have taken place in the primary sectors, in manufacturing, and in household consumption and these are reflected in an increasing emphasis on the use of fossil fuels and construction materials. Mexico's economy has been strongly influenced by international trade since the country commenced competing in international markets. In the 1970s, Mexico mainly exported primary resources. This pattern has changed and manufactured goods now have a much greater importance due to a boom in assembling industries. In contrast with other Latin American countries, Mexico has achieved a diversification of production, moving towards technology-intensive products and a better mix in its export portfolio. However, crude oil exports still represent the single most important export good. Mexico's material consumption is still well below the OECD average but is growing fast and the current resource use patterns may well present serious social and environmental problems to the medium and long term sustainability of Mexico's economy and community. Information on natural resource use and resource productivity could provide valuable guidance for economic policy planning in Mexico.
\end{abstract}

Keywords: Natural resources, resource use patterns and dynamics, physical accounting, material flows, resource use efficiency, Mexico 


\section{Introduction}

Most of the existing work devoted to the analysis of sustainable development in developing countries, and particularly those in Latin America, has been based either on monetary measures or indices ${ }^{1}$, while hardly any emphasis has been given to the development of resource use indicators to evaluate the resource requirements and related environmental impacts of economic activities. This paper contributes to a biophysical understanding of the economic process by providing a material flow accounts (MFA) for the Mexican Economy. By accounting for the material inputs into an economy, the material accumulation within the economy, and outputs to other economies or back to nature, material flow accounting provides an empirical assessment of the physical dimension of an economic system, usually expressed in tonnes or joules.

Material flow indicators are measures of pressure, and express a potential for environmental impact rather than environmental impact as such. Although there is always an environmental impact associated with the extraction and consumption of materials, the actual impact depends on the physical quantity and the impact factor per a unit of physical material flows. The indicators we present refer to 'generic impacts' (Bringezu et al., 2003) and focus on material input and consumption rather than waste and emissions. Material flow analysis studies emphasise natural resource extraction activities as an important area of negative environmental impacts (Giljum et al., 2005) For example, the considerable environmental impacts of mining on landscapes, water use and biodiversity are well documented and have been the source of important social conflicts in Latin American countries such as e.g. Peru (Muradian et al., 2003). Extensive agriculture and livestock industries have been the main cause of forest degradation and of massive changes in habitat and biodiversity loss in the Amazon area (Martinez-Alier, 2002). In Mexico, oil exploration and extraction, in addition to depleting a non-renewable natural resource, also have led to important environmental and social consequences as they conflict with existing property rights, force relocations and lead to hazardous living conditions (due to soil and water pollution), mobilise large amounts of material and require considerable amounts of infrastructure (Epstein and Selver, 2002). In addition, oil extraction requires ever higher amounts of energy (energy costs) to obtain the new fuel because production increasingly extends from shallow waters to more deepwater environments (Gately, 2007).

\footnotetext{
${ }^{1}$ For an extensive review on progress on sustainability indicators in Mexico and in Latin America in general see Quiroga (2005).
} 
Accounting for physical flows is conceptually based on the notion of social metabolism and has a long intellectual history (Fischer-Kowalski, 1998). The empirical work gained momentum in the early 1990 when a number of national case studies were published (see Fischer-Kowalski and Huettler, 1998) and international agreement on methodological standards was reached by bringing together experiences from several industrialized countries (Adriaanse et al., 1997; Matthews et al. 2000; Weisz et al., 2006). A major breakthrough in developing harmonized accounting standards was been achieved within the OECD working group on environmental information and outlooks material flow and resource productivity work (for a review see Moriguchi, 2007). More recently, material flow accounting has been applied to Latin American economies including Chile, Colombia and Ecuador (Giljum, 2004; Pérez-Rincón, 2006; Vallejo, 2006) and has allowed for the first comparative studies of Latin American resource use patterns (Amann et al., 2002; Russi et al., forthcoming).

In this paper, we provide a biophysical perspective of the Mexican economy by accounting for its material inputs during the period 1970 to 2003. Over these three decades, the Mexican economy experienced important transformations. Mexico's productive structure was modified, as a result of the implementation of radical economic reforms whose main objectives were stabilisation and growth, to be achieved through the liberalisation of the economy. The economic effects as well as the social impacts of these reforms have been thoughtfully analysed by economists (Dussel, 2002; Guillén, 2006; Chavez, 2006) but environmental impacts and implications for natural resource use have hardly been addressed. While there is a common sense that economic growth leads to increases in resource use and impacts, a number of questions have not been addressed adequately. What has been the magnitude of changes in resource use? How has resource use changed in qualitative terms? How have economic reforms affected the structure of physical trade? Was there an overall increase or decrease in resource use efficiency in the Mexican economy over recent decades?

To address these questions we structure the paper in five parts: Part I provides the economic background for Mexico, summarising the major macro-economic reforms. In part II, we outline the methodology we applied to measure material flows and to arrive at material flow indicators. In part III we analyse the pressures that economic activities exert on the natural resource endowment of Mexico by analysing the levels and trends of domestic materials extraction. Part IV describes changes in the economy's physical trade patterns as a result of the structural changes that the Mexican economy has 
undergone since the 1980's. Finally, part V analyses material input and material consumption patterns in Mexico. To do this, material flows are related to macroeconomic and social indicators in order to analyse the interface between the physical and economic dimensions. From there, we provide a first take on resource constraints and possible problems posed by current resource use patterns.

\section{Economic development in Mexico}

Since the 1940s and until the second half of the 1970s, economic development in Mexico was based on import substitution ${ }^{2}$ and state-driven industrialisation. During this period, Mexico experienced its most dynamic economic period ever. Real GDP per capita grew at an average annual rate of 3.1\%. Growth in the 1970s was based on high government investment and import substitution, and since the second half of the decade it was boosted by the oil boom.

Despite the dynamic performance of the Mexican economy during the 1970s, the economy went through a hyperinflation process and multiple crises in 1982 (debt crisis) and in 1986-1987 (oil crisis). The main factor leading to the economic collapse was the deterioration of the productive structure caused by a drastic rise in the income generated during the oil boom, a phenomenon described in the literature as the Dutch disease. ${ }^{3}$ High external debt and a high dependence on petroleum exports further contributed to the vulnerability of the economy to external shocks. During the 1980 s, the economy did not grow and per capita income decreased by about $15 \%$.

As a reaction to the crisis and in order to stabilise the economy, a neo-liberal economic programme was adopted in 1988 based on fiscal and monetary restrictive policies, multiple currency devaluations, an opening of the economy and an increasing reliance on market forces instead of government planning. In 1986, Mexico inaugurated a set of policies aiming at stimulating free trade by joining the General Agreement on Tariffs

\footnotetext{
${ }^{2}$ The imports substitution policy regime focused on the provision of trade protection measures to domestic manufacturing. Under this regime, industrial policy operated through sector-specific programs, with the aim of building up a manufacturing sector capable of producing capital goods and intermediate products. This policy was complemented by strong state intervention to carry out investment projects to supply strategic or basic intermediate products. In addition, public enterprises were created for security reasons or to avert bankruptcies and maintain employment (Moreno-Brid et al., 2005).

${ }^{3}$ The core of the Dutch disease argument is that resource abundance in general, or resource booms in particular shift resources away from sectors of the economy that have positive externalities in growth (Sachs and Warner, 1999. p. 48). In Mexico, the drastic rise in income due to the oil boom deteriorated the overall productive structure. This development in Mexico is explained by Cardenas in detail (1998, p. 112): more income, more demand for national products and imports pushing internal prices upwards. The domestic industry sees their input prices abruptly increasing (labour, energy, construction) faster than the price of their products, thus driving profits downwards. As a result, Mexico's domestic industry was unable to compete against imported goods.
} 
and Trade (GATT) as one of the first Latin American economies to do so. By the end of 1988, the trade liberalisation of Mexico's domestic market for manufacturers was almost completed (Ten Kate and De Mateo, 1989).

Since then, Mexico has signed 12 trade agreements with 43 nations putting $90 \%$ of its trade under free trade regulations. It has also joined the OECD and the WTO. The most important trade agreement has been established with the United States and Canada (NAFTA), allowing trade to triple in monetary terms since NAFTA was ratified in 1994. Today, almost $85 \%$ of Mexico's exports are delivered to the United States, making the Mexican economy dependent on economic cycles in the US. Foreign Direct Investment (FDI) inflows have increased and helped to trigger export-oriented manufacturing, transforming Mexico's position in the world market (Moreno-Brid et al, 2005). During the period 1982-2003, Mexico went from being merely an oil-exporting country, to a significant exporter of manufactured goods.

Nevertheless, these economic reforms did not spare the economy from a new collapse. In 1994-1995, a financial crisis caused a 7\% reduction in overall economic activity. Since then, the economy has not regained the dynamism observed in the 1970s and has been unable to create enough jobs to satisfy the growing supply of labour. From 1995 to 2003, average real GDP growth was 2.5\%. As a result of the economic reforms, the economic structure was modified during the last three decades, resulting in a dominance of the services sector. In 2003 , service activities accounted for $67 \%$ of the national product, while the industrial activities produced only $27 \%$ and the primary sector accounted for an insignificant 6\% (INEGI, 2006).

In addition, the structural reforms have not led to poverty alleviation and have not improved income distribution. In 2000, 24\% of the Mexican population remained in extreme poverty ${ }^{4}$, the same level that had been observed in 1968, over thirty years earlier (Szekely, 2005). The Gini index was 0.48 in 2000, almost the same as in 1977 (0.49) and today, the top $20 \%$ of income earners receive $55 \%$ of total income in the country (WB, 2006). On the other hand, when compared with most other Latin America economies, Mexico still has a privileged position despite economic instability. In 2003 , Mexico had the highest per capita GDP in the Latin American region $(\$ 6,770$ in current US dollars in 2003) and was considered a middle- income country by the World Bank.

\footnotetext{
${ }^{4}$ The notion of extreme poverty used here refers to poverty measured as incapacity to obtain food. In the same year, $53.7 \%$ of the population were unable to establish their own family (Szekely, 2003) which is another indicator for lack of means.
} 


\section{Physical accounting methodology}

Material flow accounting has become the standard approach in environmental accounting and reporting on the flow of materials related to economic activities. By establishing a satellite account to the national accounts reporting on material flows, MFA complements the system of national accounts for resource use caused by and enabling economic activity.

Applying MF accounting methodology for the input side means that all material inputs of a national economy are accounted for, apart from water and air, which are not directly embodied in material inputs. In order to make the data set for Mexico internationally comparable, the standard EUROSTAT methodology for economy-wide MFA (EUROSTAT, 2001) was applied. Only direct flows (i.e. inflows with an economic value, namely used flows) were accounted for, ignoring all unused and indirect flows, i.e. those flows that are not directly exchanged on the market but are associated with the extraction of raw materials (e.g. overburden from mining processes) as well as materials required to produce imported goods. The main material sub-categories we looked at in our accounts were biomass, fossil fuels and minerals. Biomass comprises the subcategories of food, fodder, living animals, timber and other biomass. Fossil fuels comprise coal, oil, natural gas and other fossils while the category Minerals includes industrial minerals, metal ores and construction minerals.

Similar to traditional National Accounts, MFA aggregated indicators are derived from material flow data sets. The macro indicators from physical accounting presented in this analysis are all input, consumption and balance indicators focussing mainly on the input side of the economy. Table 1 provides an overview of the aggregated indicators we used for our analysis. For a detailed description of the methods applied and data sources used in the compilation of the data set see Gonzalez-Martínez (2007). 
Table 1. Material categories and MFA indicators calculated in this study

\begin{tabular}{|c|c|c|}
\hline $\begin{array}{c}\text { Material } \\
\text { cateqories }\end{array}$ & Indicators & Description \\
\hline \multirow{3}{*}{ Biomass } & $\begin{array}{l}\text { Domestic Material } \\
\text { Extraction } \\
\text { DE }\end{array}$ & $\begin{array}{l}\text { Raw materials and biomass } \\
\text { extracted within national borders }\end{array}$ \\
\hline & $\begin{array}{l}\begin{array}{l}\text { Direct Material Input } \\
\text { (DMI) }\end{array} \\
\text { DMI = DE + imports }\end{array}$ & $\begin{array}{l}\text { DMI comprises all materials that } \\
\text { enter the economy for further use, } \\
\text { either for production or consumption } \\
\text { processes }\end{array}$ \\
\hline & $\begin{array}{c}\text { Domestic Material } \\
\text { Consumption (DMC) } \\
\text { DMC= DMI - exports }\end{array}$ & $\begin{array}{l}\text { DMC provides information on the } \\
\text { quantity of the materials that remain } \\
\text { within the national territory }\end{array}$ \\
\hline \multirow[t]{3}{*}{ Minerals } & Imports & $\begin{array}{l}\text { All imports from raw materials to final } \\
\text { goods, expressed in tonnes of traded } \\
\text { flows when they cross the national } \\
\text { boundary }\end{array}$ \\
\hline & Exports & $\begin{array}{l}\text { All exports from raw materials to final } \\
\text { goods, expressed in tonnes of traded } \\
\text { flows when they cross the national } \\
\text { boundary }\end{array}$ \\
\hline & $\begin{array}{c}\text { Physical Trade Balance } \\
\text { PTB }\end{array}$ & $\begin{array}{l}\text { PTB is accounted for by deducting } \\
\text { exports from imports. Thus, PTB is } \\
\text { the reverse of the monetary trade } \\
\text { balance. A positive figure for PTB } \\
\text { would refer to a net importer while a } \\
\text { negative figure would indicate a net } \\
\text { exporter of materials. }\end{array}$ \\
\hline
\end{tabular}

\section{Extraction of materials in Mexico}

The first biophysical indicator we calculated, namely Domestic Material Extraction (DE) counts the amount of materials extracted within the borders of the economy. Thus, it is a straightforward indicator of pressure exerted on the domestic environment. The level of $D E$ depends to large extent on the spatial distribution and regional availability of resources (EUROSTAT, 2002). Mexico is a big country (1.9 million $\mathrm{km}^{2}$ ) with diverse climatic conditions, ranging from tropical forest in the South to dry deserts in the North, suggesting a big potential for resource extraction.

Unperturbed by the ups and downs of the economy, domestic extraction of materials in Mexico consistently increased over the last three decades. In those thirty years, domestic extraction tripled from 349 million tonnes in 1970 to 1,148 million tonnes in 2003. In per capita terms, it increased from 7.4 to 11.2 tonnes between 1970 and 2003, 
a considerable amount if we take into account that average global resource extraction was 8.2 tonnes per capita in 1999 (Eisenmenger and Schandl, 2006).

Figure 1. Domestic extraction of materials in Mexico 1970-2003, in million tonnes

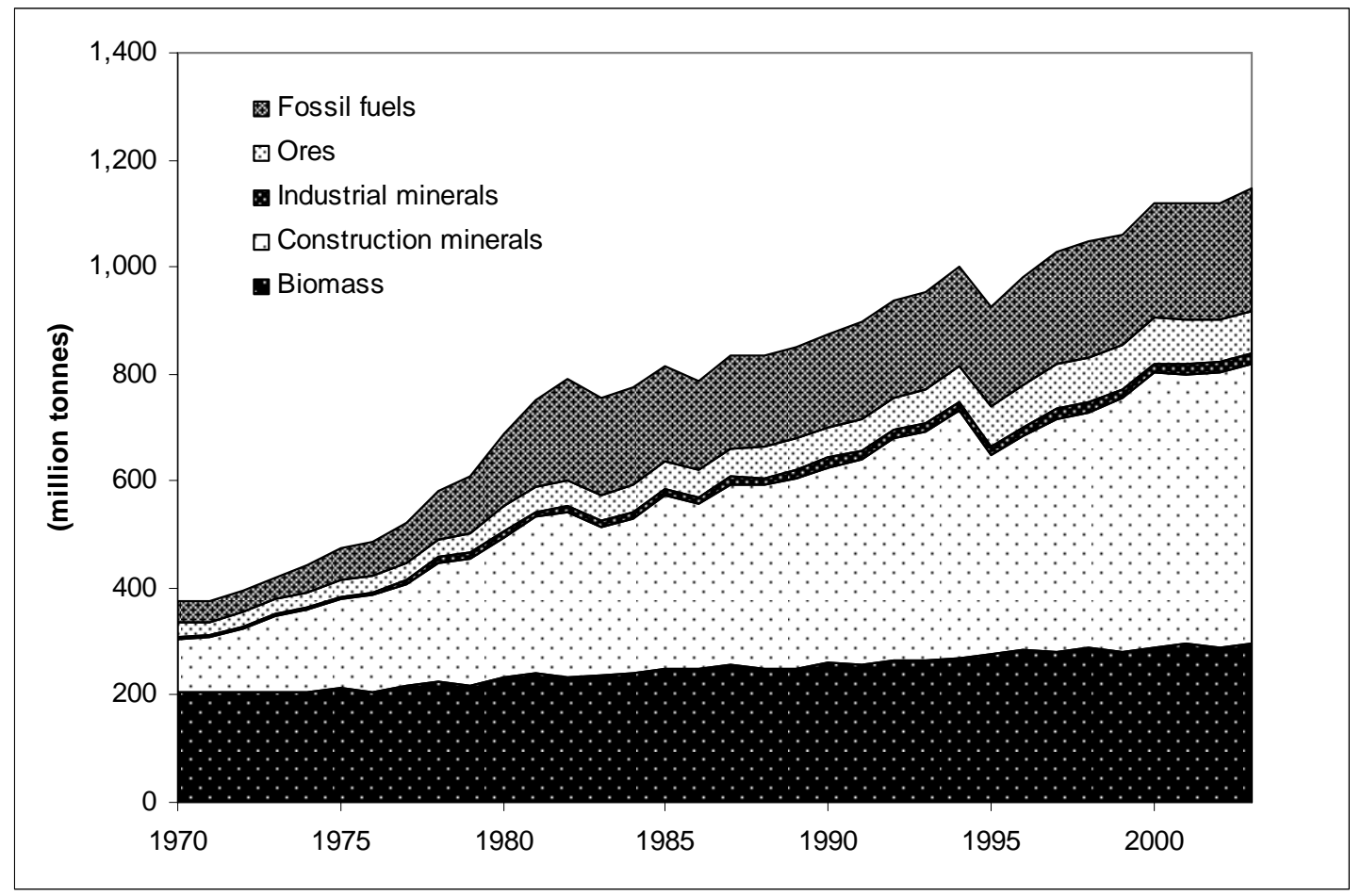

Source: Gonzalez-Martinez (2007)

As Figure 1 shows, the composition of domestic material extraction also underwent an important change between 1970 and 2003. The most pronounced feature is the considerable rise in the quantity of minerals and fossil fuels domestically extracted since 1970. The categories increased by a factor 5 and 6 , respectively, during the three decades. As a consequence, the relative importance of biomass extraction dropped from $54 \%$ to $26 \%$, marking an important change in Mexico's resource base, away from traditional, land based resources to new industrial resources. During this period, fossil fuels increased from an $11 \%$ share to a $20 \%$ share. By 2003 , the largest portion, by far, of domestic materials extraction was minerals, and in particular construction minerals, with a proportion of $54 \%$ and $45 \%$ respectively. The ongoing industrialization and urbanization of the Mexican economy and a growing population went hand-in-hand with infrastructure and housing requirements (reflected by the large amounts of building materials) and energy demand (increasing extraction of fossil fuels).

In Mexico, government institutions played an important role for financing the construction of dwellings. In the 1970s, public credit institutions were created (INFONAVIT and FOVISSTE) to increase private house ownership. The year's 1970 
to1980 were the most dynamic period in house building. Dwellings increased from 8 million to 12 million during this decade (4.6\% annual growth rate). The following two decades were less dynamic because of economic slowdown and crisis. The annual growth rate for new buildings during $1980-1990$ was 3.3\% and 3.4\% in the period 1990 2000 (INEGI; 2008). In the years of economic crises, credits for housing and other construction activities were constrained; for instance, GDP in the construction sector decreased by $23.5 \%$ during the economic crisis in 1994-1995 (INEGI, 2006). Investments in infrastructure construction followed a cyclic pattern as well. Government expenditure decreased during the economic crises. For instance in 1995, expenditure in infrastructure decreased by $33 \%$.

Nevertheless, according to material flow indicators, the general growth trend for construction minerals seemed to be unaffected by economic fluctuation, although in critical years such as 1982 and 1994-1995, extraction of construction minerals decreased along with the contracting economy. This only partly confirms the findings of other case studies (Giljum et al. 2005; Weisz et al., 2006), that the absolute level of building materials extraction would be determined by GDP/capita levels and the more an economy grows, the more infrastructure it needs and therefore it would demand more building materials. It needs further investigation to disaggregate the overall trend found into its components, to identify the impact of construction activities for dwellings and infrastructure, on overall demand for construction minerals.

\section{Mexico's Trade patterns and their physical consequences}

Besides of the considerable growth dynamics observed for the extraction of natural resources, the integration of Mexico into global markets, as expressed by the amount of materials traded, has been impressive. Trade flows have shown a dramatic rise in terms of weight during the period under study. Annual imports have grown from 8.5 to 185 million tonnes and exports have grown from 14 to 243 million tonnes, resulting in a yearly growth rate of $9.8 \%$ and $9.05 \%$ respectively.

As Figure 2 shows, the development of trade should be split in two main periods with different characteristics. The first period, from 1970 to 1986, was characterised by fast growing exports boosted mainly by the oil boom while imports remained fairly constant, because Mexico's main trade policy was focussed on import substitution. The second period, from 1987 onwards, was characterised by fast growing imports, caused by reduced trade barriers and more international trading agreements. In this phase 
exports grew at a much slower pace. As a consequence, the physical trade balance (PTB) obtained by deducting exports from imports also underwent change in the late 1980s, from a negative balance (net exports) to a positive balance (net imports), except for the years 1994 and 1995 (when the Mexican economy experienced a financial crisis) and for the year 2003. However, the monetary trade balance (MTB) was negative for most of the period, apart from some critical years such as 1982-1989 and 19951996 when imports were constrained due to contractions of domestic demand (Moreno-Brid et al., 2005). Interestingly, during the 1970s physical exports where higher than imports while the value of exports was lower than that for imports, resulting in a negative monetary balance and a negative physical balance, indicating the unfavourable position of the Mexican economy in the World market in the 1970s.

Figure 2. Physical Imports, Exports and Physical Trade Balance (PTB) of Mexico 1970-2003, in million tonnes

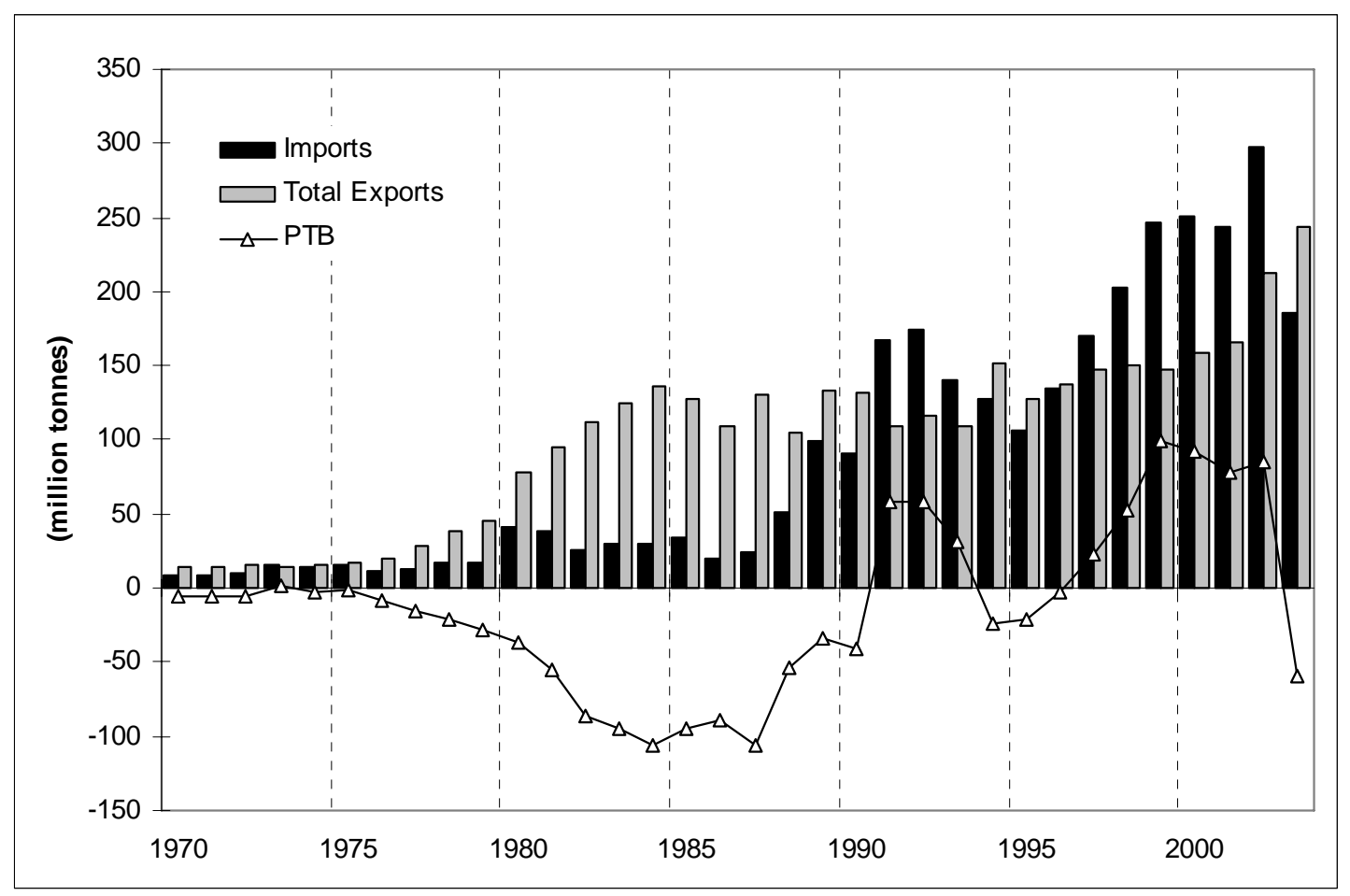

Source: Gonzalez-Martinez (2007)

This imbalance becomes more evident when analysing the unit prices of imports and exports. Figure 3 shows the price of imports and exports for Mexican trade from 19702003. During the 1970 s and even the 1980s, the price per tonne of imports was considerably higher than the price per tonne for exports. This difference decreased markedly from 1982 on when the unit price of exports increased faster than the price of 
imports (from \$86/tonne, to $\$ 1,046 /$ tonne in 2000 and \$676/tonne in 2003). In the 1970s, Mexico was mainly an extractive economy, selling raw materials cheaply to the world market but relying on imports of expensive finished products. The overall effect of this unfavourable position was alleviated by an import substitution policy but nevertheless could not ease the social and economic consequences of resource exports. Such an economic pattern is resource and pollution intensive, results in a lack of sufficient infrastructure development and insufficient incomes for communities and households, and is highly vulnerable to market fluctuations (Bunker, 2007). For comparative purposes, note that in the EU-15 the average price for an imported tonne was $\$ 1,559$ in 2000 , about one third of the price for an exported tonne $(\$ 5,306)$, both numbers being significantly higher than those for Mexico (EUROSTAT, 2002).

Figure 3. Unitary price of imports and exports in Mexico 1970-2003, in US dollars (2000 prices) per tonne

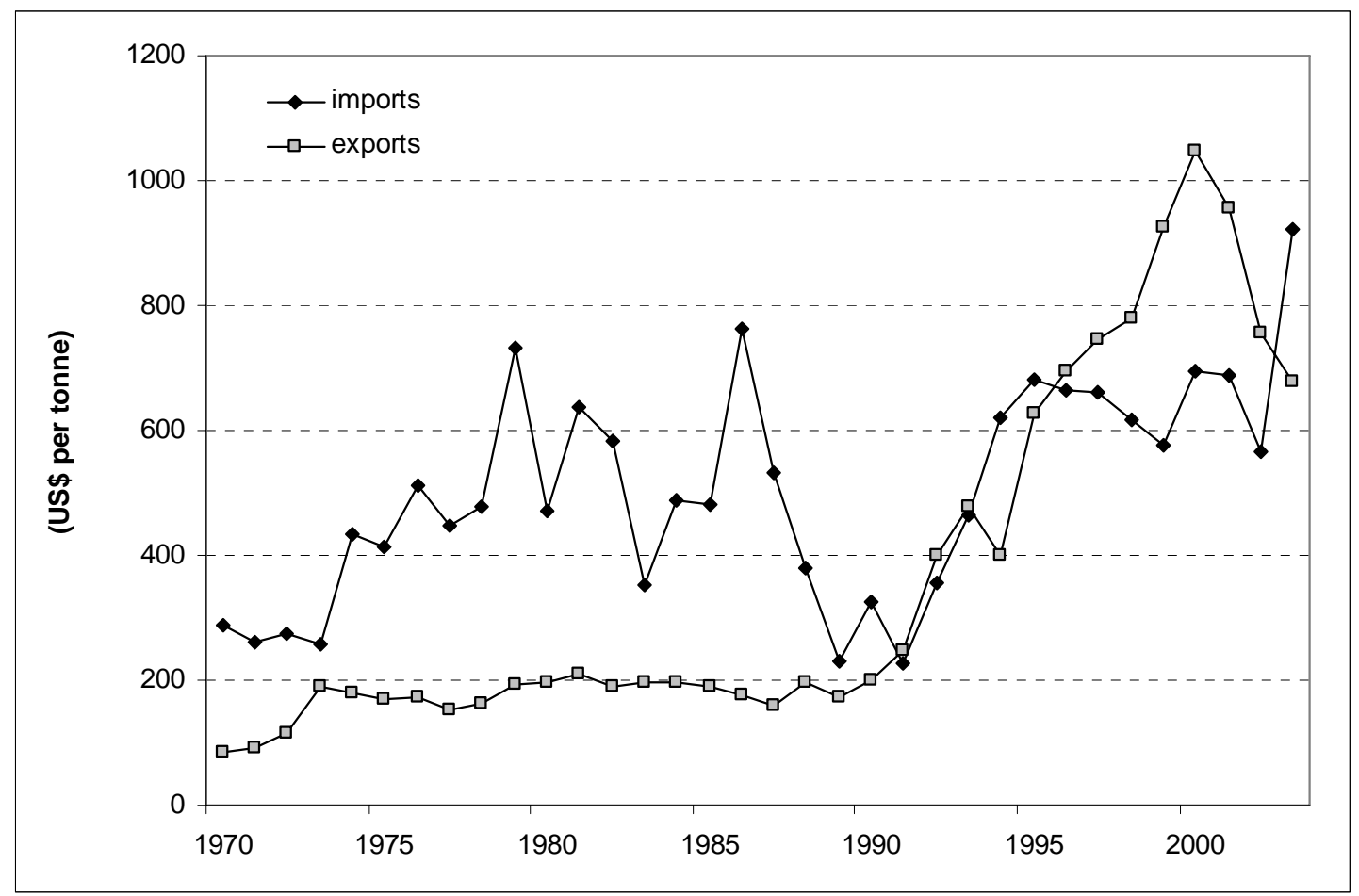

Source: Gonzalez-Martinez (2007), World Bank (2005)

The reason for this marked change in Mexico's trade can be found in the composition of traded goods, caused by structural changes in the Mexican economy. Apart from the overall growth experienced in Mexican trade, the composition of imports and exports, measured in tonnes, has also undergone important changes in the period under study. In the early 1970s, minerals (comprising raw materials, semi-manufactured products and final products) dominated imports (37\%). In particular, semi-manufactured metal 
products and raw metals were the dominating fractions contributing three quarters of total mineral imports. The second most important import-flow was fossil fuels (36\%).

By 2003, minerals increased their importance to account for $64 \%$ of all imports. However, the composition of raw materials and final products in mineral imports has changed markedly since the 1970s. Semi-manufactured products and finished products accounted for $87 \%$ of total mineral imports, while raw minerals accounted for only $10 \%$. This shift to more processed goods in imports was the reason for increasing unit prices of imports The fact that most of these products were used by the assembling industry ('maquila') ${ }^{5}$ as inputs is of great relevance in understanding these trends, as will be explained later in this paper. Biomass was the second most important import (25\%) in 2003 , mainly because of an increasing reliance on imported food crops.

In 1970, the minerals category accounted for the biggest share of exports; in particular, raw minerals represented $49 \%$ of total exports followed by fossil fuels, accounting for $27 \%$. This pattern rapidly changed, and in 1978 , fossil fuels accounted for $53 \%$ of total exports due to the oil boom. Since then, fossil fuels have been the dominant fraction, although their relative importance has decreased in recent years. In 2003, they accounted for $50 \%$ of total export weight followed by minerals (43\%) dominated now by metal-based manufactures (34\% of total exports). It is also evident in monetary terms that Mexico, during the last two decades, has changed from being an oil-exporting country to an exporter of manufactured goods. In 2003, the manufacturing industry contributed $42 \%$ of all exports whereas in 1970 the share was only $10 \%$. In addition, from 1985 to 1994 Mexico ranked fifth among the countries with the largest increases in their share of world manufactured exports (measured in monetary terms), but in the period 1994-2001, Mexico moved into second place, just behind China (Moreno-Brid et al. 2005).

What explains this non-oil exports boom? Apart from trade liberalisation policy and foreign direct investment (FDI) inflows, a decline in internal demand forced firms to look towards external markets. Nowadays, demand from abroad is the most dynamic component of demand for Mexican products. Another key factor explaining the impressive growth in non-oil trade is the assembling industry, especially since the 1990s when this type of industry obtained economic importance. According to Dussel

\footnotetext{
${ }^{5}$ The Mexican term 'maquila' is used to refer to the practice of subcontracting to produce or assemble parts that will be used in other production processes.
} 
(2004), around 70\% of Mexico's exports of manufactured goods are produced by assembling industries using imported inputs. The components that cross Mexican borders to be assembled in this industry are accounted for as imports, whereas the final goods once assembled are directly sent abroad and therefore, they are accounted for as exports. According to De la Garza (2005) $96-98 \%$ of the total inputs used in these industries are imported. Assembling activities thus were responsible not only for the remarkable increase in Mexican trade, but also for its change in composition. According to foreign trade statistics (BANCOMEXT, 2004) exports from assembling activities accounted for $47.7 \%$ of total Mexican exports and $35.3 \%$ of all Mexican imports, in monetary terms. These activities are concentrated in the automobile, auto parts and electronics industries (Dussel, 2004).

Whether the assembling industry has positive effects for the national economy has been very controversial. Salaries prevailing in the assembling industry are low, there is a serious disconnect between the assembling industry and the other domestic industries, as most of their inputs are imported, and therefore, it has not had a spill over effect on the rest of the economy. Its contribution to domestic value added is rather limited. In addition, the environmental impacts of these activities can be high due to their geographical location. The majority of the assembling plants are located in Northern Mexico's semi-arid border regions where the combination of meteorological conditions and topological disadvantages, with dynamic industrialisation and population growth, exert a growing pressure on the environment and natural resources; mainly on water. Water scarcity is becoming a crucial issue (Stromberg, 2005).

With regard to physical trade patterns, the Mexican economy is different from other Latin American economies such as, for instance, Ecuador and Colombia. While the latter follow the typical pattern of 'extractive economies', Mexico's dependence on natural resource exports decreased in monetary terms in the analyzed period even though exports of raw materials increased in absolute values. This pattern places Mexico between the profile of a typical Latin American economy (characterized by low GDP and abundance of natural resources) and that of industrialized countries (based on strong industrial and service sector and a high dependence on imports for mineral ores, fossil fuels and other primary materials). The Mexican economy is at a crossroads between being an 'extractive economy' (Bunker, 2007) as it keeps extracting large quantities of crude oil for exporting, and a 'productive economy' as it produces an increasing quantity of manufactured products destined mainly for international markets. Whether Mexico will be able to consolidate an economy based 
on high value added processes and products, is thoughtfully debated by economists (for a review see Dussel, 2003).

\section{Material input and consumption patterns in the Mexican economy}

Material flow analysis aims to create a full description of an economy, in physical terms. The material flow-based-indicator Direct Material Input (DMI) is comprised of all materials of economic value directly used for consumption or production purposes. The indicator is calculated by adding imports to domestic extraction. In Figure 4, the evolution of DMI in millions of tonnes clearly shows the increasing quantity of materials entering the Mexican economy. DMI rose from 384 million to 1.3 billion tonnes in only three decades, equal to an increase from 7.6 to 13 tonnes per capita. Although imports are fast growing, domestic extraction of resources has been the main source of material inputs. Imports only gained importance in the 1980s. In 1970, imported materials represented only $2 \%$ of direct material input, but this increased to $14 \%$ by 2003.

Figure 4. Domestic extraction and imports in Mexico 1970-2003, in million tonnes

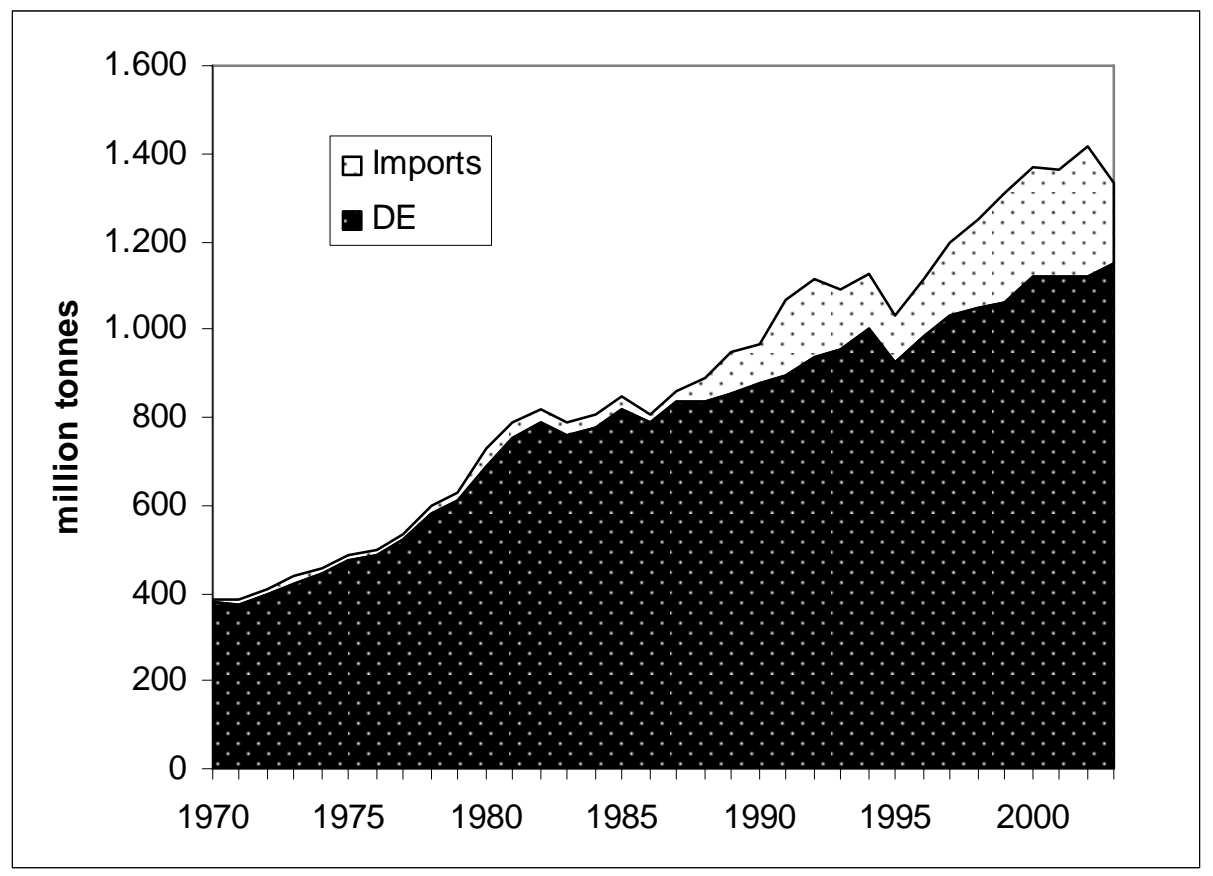

Source: Gonzalez-Martinez (2007)

Information about the evolution of resource use is of great relevance as it allows us to complete the picture of the Mexican economy. If we based our analysis only on economic data, we might wrongly conclude that as a result of the structural change, resource use and related environmental impacts of the Mexican economy have 
decreased due to the increasing importance of the service sector and the fact that services need fewer resources than primary and industrial activities ${ }^{6}$. This misconception disappears when we gain consistent information on the physical economy, showing that despite the relative increase in services in the economy, the underlying physical flows have increased dramatically. Services do not replace material intensive production and consumption processes but add economic value on top of these. Usually an increase in service sector jobs also increases domestic consumption, due to increasing wages adding to the resource requirements of the whole economy. Moreover, material flows in Mexico rose despite periods of uneven and weak economic growth.

The growing quantity of material inputs extracted domestically coincided with the decreasing economic importance of primary activities as a source of national income and as a provider of jobs. In 1970 , agriculture, forestry and fishing contributed $11.2 \%$ to gross domestic product, while mining contributed another $2.6 \%$. Today, agriculture has decreased to $3.5 \%$ of added value, and mining to $1.2 \%$, although they went up in absolute terms allowing for increasing DE. With regard to the relative importance of agriculture and mining in the economy, Mexico represents a typical developed, industrialized pattern. Unlike Mexico, other Latin American countries specialising in natural resource exports, such as Chile and Ecuador, show an increasing relative importance of primary sectors activities (Giljum, 2004; Russi et al., forthcoming).

While DMI focuses on the inputs side, the indicator Domestic Material Consumption (DMC) provides information on the quantity of the materials that remain within the national territory. It is calculated by subtracting exports from DMI. DMC comprises of all materials used (intermediate and final consumption) and has also been described as an indicator for the waste and emissions potential of an economy (Weisz et al. 2006). Because DMC includes intermediate consumption the indicator is higher when the extraction sector and industry are of greater importance. Therefore, DMC is not an indicator for final consumption.

\footnotetext{
${ }^{6}$ The environmental Kuznets curve (EKC) hypothesis wrongly assumes a reduction in materials use when economies get richer. Whilst in the early stages of development, it is argued, incomes are low and so are material requirements. Industrialization drives an increase in material demand, mainly for basic infrastructure. As development continues, the need for infrastructure is met and consumer demand shifts toward services, which are assumed to be less materials intensive (Cleveland and Ruth, 1999; Stern, 2001). While we may see stabilization for certain industrial economies, there is not a lot of evidence for overall resource use decline (Weisz et al., 2006).
} 
Figure 5. Domestic material consumption of materials in Mexico 1970-2003, in million tonnes)

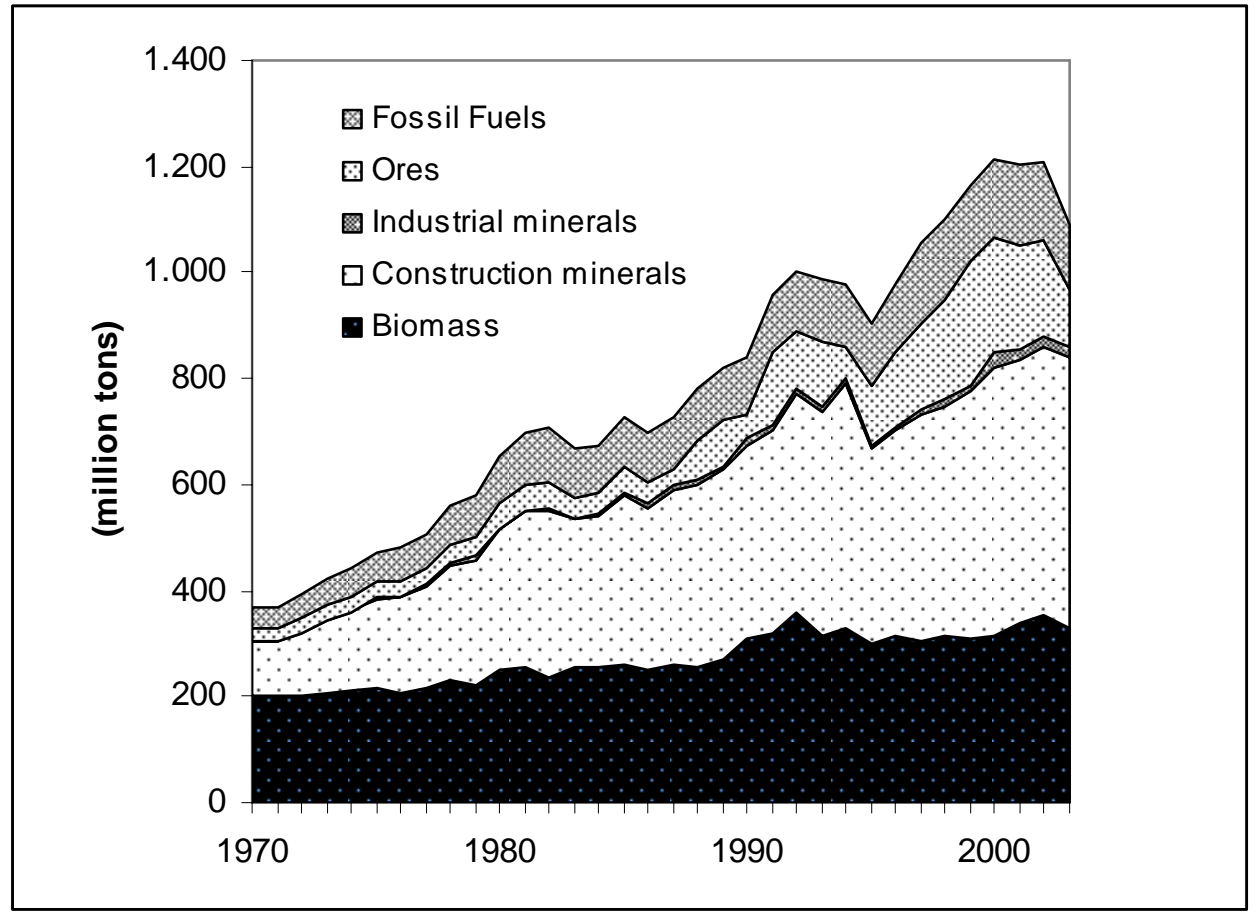

Source: Gonzalez-Martinez (2007)

Material consumption in Mexico has also grown similarly to material input. In 1970, the quantity of materials consumed was 370 million tonnes, and this increased to about 1 billion tonnes in 2003. In per capita terms, DMC increased from 7.3 to 10.7 tonnes. Figure 5 shows material consumption with breakdowns by type of material flow. Mexico has raised its material consumption mainly because of an increasing use of construction minerals while consumption of fossil fuels and biomass went up at much slower pace. In 2003 , building minerals accounted for $47 \%$ of total materials (see table 2). The shares of other flow categories either slightly grew, as was the case for fossil fuels (from $10.8 \%$ in 1970 to $14 \%$ in 1980 and $12 \%$ in 2003), or decreased as did biomass consumption (from 55\% in 1970 to $30 \%$ in 2003). 
Table 2. Domestic material consumption by material categories (\% share)

\begin{tabular}{|clcccc|}
\hline \multirow{2}{*}{ TOTAL } & & $\mathbf{1 9 7 0}$ & $\mathbf{1 9 8 0}$ & $\mathbf{1 9 9 0}$ & $\mathbf{2 0 0 3}$ \\
Biomass & & 100.0 & 100.0 & 100.0 & 100.0 \\
& Food crops & $\mathbf{5 4 . 9}$ & $\mathbf{3 8 . 7}$ & $\mathbf{3 6 . 9}$ & $\mathbf{3 0 . 0}$ \\
& Fodder & 16.4 & 13.2 & 11.2 & 10.9 \\
& Animals & 33.7 & 21.5 & 17.9 & 15.2 \\
& Timber & 0.1 & 0.2 & 1.4 & 0.3 \\
& Non edible biomass & 4.3 & 3.3 & 5.9 & 3.0 \\
Minerals & & 0.4 & 0.5 & 0.4 & 0.5 \\
& & & & & \\
& Construction minerals & $\mathbf{3 4 . 3}$ & $\mathbf{4 7 . 7}$ & $\mathbf{5 0 . 5}$ & $\mathbf{5 8 . 3}$ \\
& Industrial minerals & - & 39.8 & 43.5 & 46.9 \\
& Ores & - & 0.1 & 1.3 & 1.8 \\
& & - & 7.9 & 5.7 & 9.6 \\
Fossil Fuels & & & & $\mathbf{1 1 . 7}$ \\
& & $\mathbf{1 0 . 8}$ & $\mathbf{1 3 . 6}$ & $\mathbf{1 2 . 6}$ & 1.3 \\
& Coal and products & - & 0.3 & 0.5 & 8.0 \\
& Crude oil and products & - & 9.5 & 9.0 & 2.4 \\
\hline
\end{tabular}

Source: Gonzalez-Martinez (2007)

The marked increase in mineral use is linked to a prevalent urbanisation trend (Garza, 1999) and the growing importance of manufacturing and related built infrastructure. The much slower increase in fossil fuels consumption compared to increase in industrial output suggests a decline in energy intensity in the industrial sector. In fact, energy intensity, measured in mega joules per unit of GDP, has been declining since 1988 (Aguayo and Gallagher, 2005). In addition, per capita household energy consumption increased by only $13 \%$ over the last three decades, from 6,201 PJ to 7,055 PJ. Less than half of the total energy consumption of the residential sector, namely $42 \%$, stems from fossil fuels. Fuel wood is still an important factor in household energy consumption, especially in rural areas, and accounts for $36 \%$ of residential energy use (SENER, 2007). A study by Masera et al. (2005) suggests that $80 \%$ of the energy demand in rural areas is supplied from fuel wood. Per capita fossil fuel consumption in Mexico is similar to Chile (Giljum, 2004), which also has a similar per capita GDP but lacks significant fossil fuel reserves. In the year 2000, fossil fuel consumption in the EU-15 was three times higher than in Mexico and Chile, at 3.7 tonnes per capita (Eurostat, 2002).

Although there was a slight growth in biomass consumption in absolute terms, DMC per capita for biomass decreased from 4 tons to 3.2 per capita over the period 1970 to 2003. This decrease was related to fodder for livestock. This flow is mainly comprised of grass uptake by ruminants on permanent pastures, and it is affected by high uncertainty as it has to be estimated indirectly. Direct fodder uptake is not usually reported in agricultural statistics and, in the case of Mexico, it was estimated following 
the standard procedure used in Eurostat (2002) in order to narrow down the range of uncertainty. The drop per capita should not be related to technological improvements or a decrease in the land used for permanent pastures. In fact, between 1970 and 2003 , permanent pastures slightly increased from 74,500 to 80,000 thousand hectares a result of increases in livestock from 45 million to 54 million heads.

Relating DMC to indicators of economic performance such as GDP or GNP allows for assessing the intensity of material use in an economy. The ratio DMC/GDP (material intensity) indicates the quantity of materials used per unit of economic output. Figure 7 shows that material intensity in Mexico has been fairly stable during the last three decades despite structural change and the increasing importance of manufacturing industries in GDP. Material intensity fluctuated between 1.8 and $2.2 \mathrm{~kg}$ of materials per USD. In addition, figure 6 provides evidence that dematerialisation has not happened. In order to gain a complete picture of the overall material intensity, the indirect upstream flows related to imports would have to be appropriately measured and included in the analysis.

Figure 6. Evolution of material flow indicators and GDP 1970-2003, in million tonnes and billion US dollars, at 2000 prices

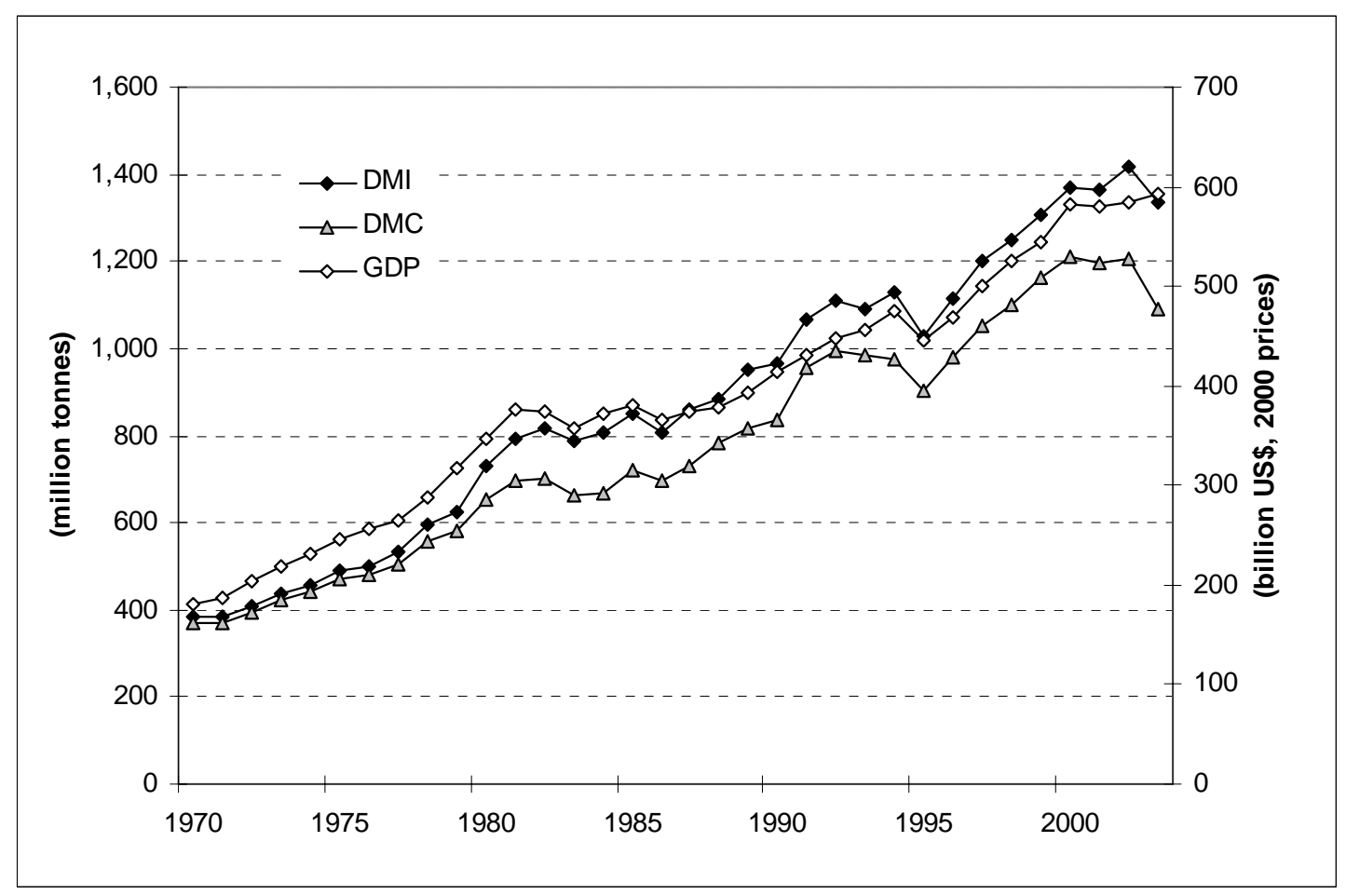

Source: Gonzalez-Martinez (2007), World Bank (2005) 
The reasons why there has been little progress in material efficiency in the Mexican economy is that, apart from a few privileged sectors oriented towards exports, innovation has been rare. Only few sectors have been able to close the technological gap, while the majority of the national industry has not solved the deeply-rooted structural problems. The pressing problems are a lack of long-term financial resources and insufficient investment to modernise industrial businesses. Indeed, during the eighties, fixed domestic capital formation in machinery and equipment registered an annual negative growth rate of $1 \%$. By the end of the eighties, investment in machinery and equipment recovered to a positive growth rate. From 1988 to 2003, the annual average growth rate was $6.7 \%$, still below the annual rate of $8 \%$ during the 1970 s (Banco de Mexico, 2007; INEGI, 2007). Although the Mexican economy has not achieved a consistent delinking between resource use and economic growth, the overall material efficiency is more favourable than in many other Latin American countries such as Ecuador, Chile and Peru. Compared to these economies, Mexico is more material-efficient (Russi et al.; forthcoming) but still by far below the EU-15 material-efficiency level, which was at $1.2 \mathrm{~kg}$ per USD in 1980 and further improved to $0.8 \mathrm{~kg}$ per USD in 2000 (EUROSTAT, 2002).

Figure 7. Material intensity of the Mexican economy 1970-2003, in kg per US dollar

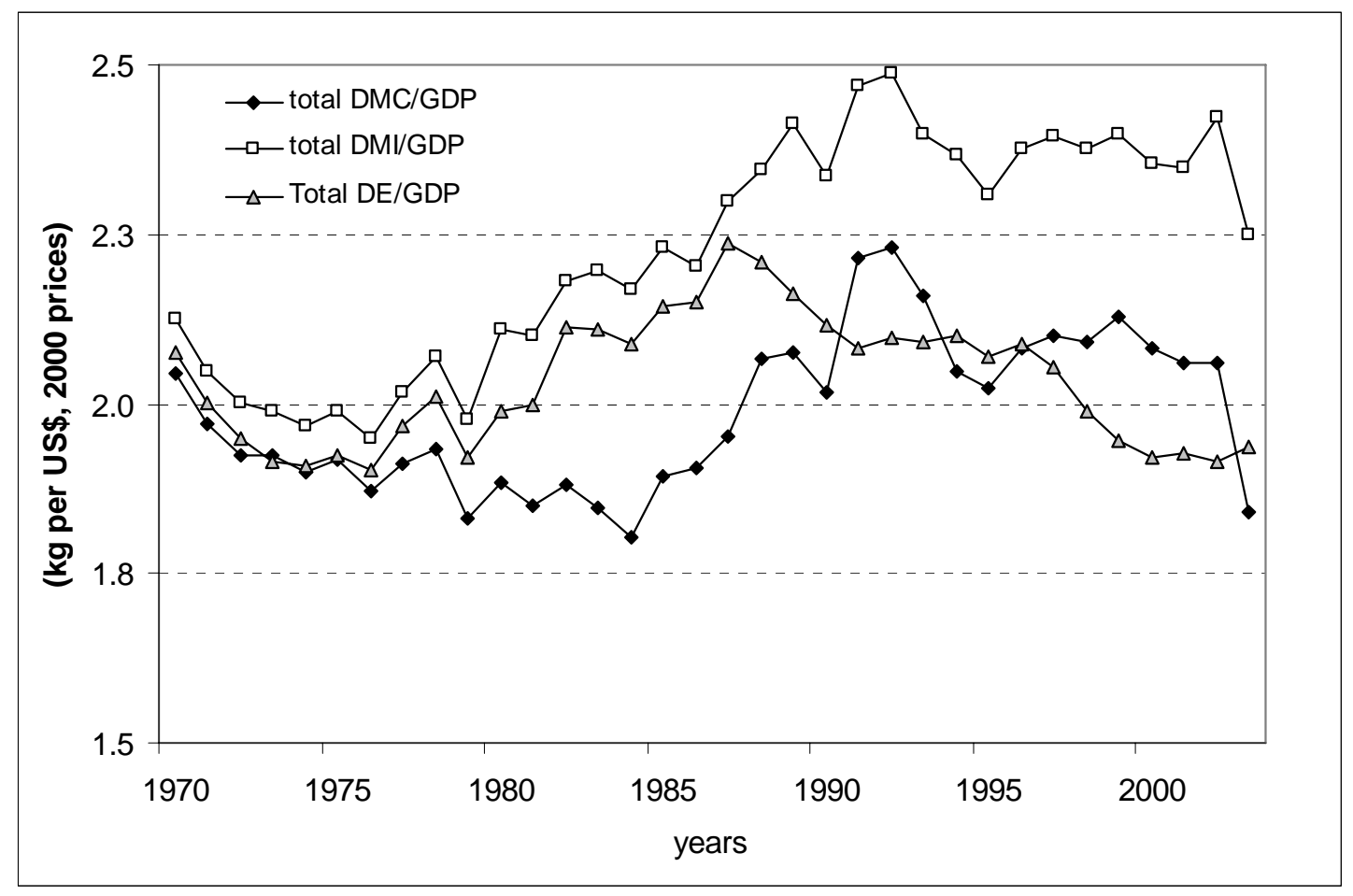

Source: Gonzalez-Martinez (2007), World Bank (2005) 
We apply the IPAT model (Holdren and Ehrlich, 1971) in order to analyse the main socio-economic driving forces of material consumption. We interpret DMC as a proxy for environmental impact (I) and use a mathematical formula with three variables: population $(P)$, GDP per capita to indicate affluence $(A)$, and DMC/GDP as a technology indicator $(T)$. Our objective is to determine which of these three variables explains the material consumption trends in Mexico. The IPAT equation using the material consumption indicator has been formulated as follows (EUROSTAT, 2002):

$$
\text { DMC }=(\text { Population }) *(G D P / \text { population }) *(D M C / G D P)
$$

Table 3 shows the evolution of the relevant variables over different sub-periods. During the whole period $1970-2003$, domestic material consumption increased by $194 \%$. This growth was influenced by a population growth of $102 \%$, a growth in affluence of $62 \%$ and an efficiency gain of $10 \%$.

Table 3. Evolution of main components of the IPAT equation

\begin{tabular}{|lllcc|}
\hline & DMC & POP & GDP/POP & DMC/GDP \\
\hline $1970-2003$ & 2.94 & 2.02 & 1.62 & 0.90 \\
$1970-1980$ & 1.76 & 1.34 & 1.43 & 0.92 \\
$1980-1990$ & 1.28 & 1.23 & 0.97 & 1.10 \\
$1990-2003$ & 1.30 & 1.23 & 1.16 & 0.91 \\
\hline
\end{tabular}

Source: Gonzalez-Martinez (2007)

Population growth was the main driving force for material consumption over the whole period. In the 1970s, per capita GDP was the fastest growing factor, supported by the oil boom. The efficiency of resource use increased although at a lower pace (8\%). In the following two decades population growth was the main driving factor. In the 1980 s, when the economy was in recession, both per capita GDP and efficiency of resource use decreased. In the most recent period (1990-2003), GDP grew slowly and resource use improvements increased by $9 \%$.

\section{Conclusions}

This study presents information on material inputs into the Mexican economy for the first time and adds evidence to other studies done for the region of Latin America. Information on the biophysical aspects of the Mexican economy have been gathered by applying standard methods for material flow accounting, and results are therefore internationally comparable. In particular, the MFA indicators obtained for Mexico are helpful to analyse the pressure this economy exerts on its natural resource 
endowment. In this sense, our first finding is that the quantity of materials entering into the economy constantly increased, despite structural change and modest economic growth. Over the last three decades, population growth and export industries were the main driving forces for the increasing use of natural resources in Mexico. Efficiency gains were relatively small, and despite rapid growth in resource use, increases in the material standard of living have been slower and unevenly distributed.

The economic reforms implemented in Mexico in the 1980s were based on an intensive use of natural resources: firstly, domestic extraction of materials in Mexico tripled due to a rapid increase of construction minerals and fossil fuels extraction. Secondly, the amount of materials traded increased considerably from the late eighties when Mexico drastically reduced all trade barriers: imports grew by a factor of 22 during the period while exports increased by a factor of 17 . The impressive growth of exports occurring in the late 1970s was solely based on fossil fuels. From the late 1980s onwards this pattern changed as manufactured products gained importance. Using MFA indicators, it was noted that Mexico has moved away from being an oil-exporting country to become an exporter of mainly manufactured goods. The assembly industry has played a crucial role in this process. While the oil based boom was based on the exploitation of a natural resource, the new export boom based on the assembling industries results from comparably low labour costs in Mexico. In this sense, the Mexican economy represents a different pattern when compared with other Latin American economies. Its dependence on exports of bulk commodities in the monetary trade balance decreased during the period analyzed, which situates Mexico between an 'extractive' and a 'productive economy' (Bunker, 2007).

Nevertheless, material intensity in Mexico has not improved during the last three decades, despite structural change and the increasing importance of manufacturing industries in the national product. The reason is that most national industries have not improved production processes and technology, apart from a few sectors oriented towards exports.

Despite efforts to diversify exports, crude oil exports still represent $50 \%$ of total exports in weight. The fact that Mexico is still basing its economic growth to a large extent on the depletion of a non-renewable natural resource, namely oil, will raise problems for the mid and long term sustainability of the Mexican economy. Already, the weak 
environmental accounting literature ${ }^{7}$ has extensively discussed how ephemeral economic prosperity built on depletion of natural resources can be. The biophysical analysis of the Mexican economy adds information on real amounts of resources used in economic processes, about the efficiency of resource use and has a potential to inform policy planning.

\section{Acknowledgements}

The authors wish to thank Tom Measham, Karin Hosking and Graham Turner for commenting on an earlier manuscript as well as two anonymous reviewers for their helpful comments. In particular, we would like to thank Joan Martinez-Alier for inspiring and advocating for material flow work in Latin American countries. The research presented in this paper was partly financed by the Spanish Ministry for Education and Science (SEJ 2006-15219/ECON "Metabolismo Social: tendencias, conflictos y respuestas").

\section{References}

Adriaanse, A., S. Brigenzu, A. Hammond, Y. Moriguchi, E. Rodenburg, D. Rogich and $\mathrm{H}$. Schuetz, 1997. Resource flows. The material basis of industrial economies. World Resource Institute, Washington DC.

Aguayo, F. and K. Gallagher, 2005. Economic reform, energy and development:: the case of Mexican manufacturing. Energy Policy 33: 829-837.

Amann, C., W. Bruckner, M. Fischer-Kowalski, and C. M. Grünbühel, 2002. Material flow accounting in Amazonia. A tool for sustainable development. Amazonia 21. Social Ecology working paper 63. IFF.

Banco de Mexico, 2007. Informacion financiera y economica. www.banxico.org.mx

${ }^{7}$ The risks of economies based on extraction and not on transformation was underlined by El Serafy (1989), who differences between economic growth based on the use of exhaustible resources (a finished stock) and growth obtained through labour, capital investment, technological progress and efficient organization (flows). The latter lays the basis for a durable improvement of life conditions whereas the former can be linked to the liquidation of a natural capital. Authors such as El Serafy (1989) and Repetto (1989) propose methodologies based on monetary measures to include natural resources depreciation into national accounts. Environmental accounting based on monetary measures of natural resources can be regarded as belonging to the weak sustainability approach assuming a potential substitution between different types of capital. 
BANCOMEXT, 2004. World trade atlas. Banco de Comercio Exterior, Mexico, DF.

Bringezu, S., Schütz, H., Moll, S. 2003. Rationale for and interpretation of economywide materials flow analysis and derived indicators. Journal of Industrial Ecology. 7(2), 43-64.

Bunker, S., 2007. Natural values and the physical inevitability of uneven development under capitalism. In Hornborg A., J. McNeill and J. Martinez-Alier, Eds. Rethinking Environmental History. World-System History and and Global Environmental Change. pp. 239-258. Altamira Press, USA.

Chavez, M., 2006. La quimera neoliberal mexicana. In Nadal, A. and F. Aguayo, Eds. Experiencias de crisis y estrategias de desarrollo. Autonomía económica y globalización. Mexico: El Colegio de Mexico.

Cleveland, C.; Ruth, M., 1999. Indicators of dematerialization and the materials intensity of use. Journal of Industrial Ecology, 2 (3), 15-50.

Dussel, E., 2002. México en la globalización y la apertura comercial. In Política Económica para el desarrollo sostenido con equidad. Tomo II. (eds J. L. Calva. Mexico: Casa Juan Pablos/ Universidad Autónoma de Mexico.

Dussel, E., 2003. Ser o no ser maquila. ¿Es esa la pregunta? Comercio Exterior. 53 (4).

De la Garza, E., 2005. La maquila en méxico: Aspectos generales. In Modelos de Producción en la Maquila de Exportación. La Crisis del Toyotismo Precario. (ed De la Garza, E.), pp. 1-19. UAM I- Plaza y Valdés, Mexico.

Eisenmenger, N.; Schandl, H., 2006. Regional patterns in global resource extraction. Journal of Industrial Ecology, 10 (4), 133-147.

El Serafy, S., 1989. The proper calculation of income from depletable natural resources. In Environmental Accounting for Sustainable Development (eds. Y.Ahmad, Y, Serafy, S. and E. Lutz. UNEP- World Bank Symposium, Washington D.C. pp.10-18.

Epstein, P; J. Selver ,2002. Oil. A life cycle analysis of its health and environmental impacts. Boston: The Center for Health and the Global Environment. Harvard Medical School.

EUROSTAT, 2001. Economy-wide material flow accounts and derived indicators. A methodological guide. Office for Official Publications of the European Communities, Luxemburg.

EUROSTAT, 2002. Material use in the European Union 1980-2000: indicators and analysis. European Commission, Luxemburg.

Fischer-Kowalski, M., 1998. Society's metabolism. the intellectual history of material flow analysis. part I, 1860-1970. Journal of Industrial Ecology, 2 (1), 61-78.

Fischer-Kowalski, M. and W. Huettler, 1998. Society's Metabolism. The Intellectual History of Material Flow Analysis, Part II, 1970-1998, Journal of Industrial Ecology 2 (4), 107-136. 
Garza, G., 1999. Global economy, metropolitan dynamics and urban policies in Mexico. Cities 16 (3): 149-170.

Gately, M., 2007. The EROI of U.S. offshore energy extraction: A net energy analysis of the Gulf of Mexico. Ecological Economics. 63, 355-364

Guillen, H., 2006. El modelo mexicano de desarrollo: balance y alternativas. In Experiencias de crisis y estrategias de desarrollo. Autonomía económica y globalización. (eds. Nadal, A. and F. Aguayo). Mexico: El Colegio de Mexico.

Giljum, S., 2004. Trade, material flows and economic development in the south: The example of Chile. Journal of Industrial Ecology, 8, 241-261.

Giljum, S., A. Behrens, D. Jölli, K. Vogt, J Kovanda and S. Niza, 2005. MOSUS. material input data for the GINFORS model. technical report. Project of the International Human Dimensions Programme (IHDP-IT). Project number: E/2003/01.

Gonzalez-Martinez A. C., 2007. Material flow accounting of Mexico (1970-2003): Sources and methods. UHE/UAB-1.2007 Working Paper. January, 2007.

Holdren J. and P. Ehrlich, 1971. Impact of population growth. Science 171: 1212-1217.

INEGI (Instituto Nacional de Estadística, Geografía e Informática), 2006. Banco de Información Económica. Mexico: Gobierno de los Estados Unidos Mexicanos. www.inegi.gob.mx

INEGI (Instituto Nacional de Estadística, Geografía e Informática), 2007. Sistemas de Cuentas Nacionales de México. http://www.inegi.gob.mx/est/default.aspx?c=1617

INEGI (Instituto Nacional de Estadística, Geografía e Informática), 2008. Censos de población y vivienda. http://www.inegi.gob.mx/inegi/default.aspx?s=est\&c=10202

Martínez-Alier, J., 2002. The environmentalism of the poor. A study of ecological conflicts and valuation. Cheltenham, UK: Edward Elgar.

Masera, O., A. Velázquez, M. Ordoñez, R. Drigo and M. Trossero, 2005. Fuel wood "hot spots"in Mexico: A case study using WISDOM- woodfuel integrated supplydemand overview mapping, 1st edn. FAO, Rome.

Matthews,E., C. Amann, S. Brigenzu, M. Fischer-Kowalski, W. Huettler, R. Kleijn, Y. Moriguchi, C. Ottke, E. Rodenburg, H. Schandl,, H. Schuetz, E. van der Voet and H. Weisz, 2000. The weight of nations. Material outflows from industrial economies. World Resource Institute, Washington DC.

Moreno-Brid, J., J. Rivas and J. Santamaria, 2005. Mexico: Economic growth exports and industrial performance after NAFTA. CEPAL, United Nations, Mexico.

Moriguchi, Y., 2007. Material flow indicators to measure progress toward a sound material-cycle society. Journal of Material Cycles and Waste Management. 9 (2): 112120. 
Muradian, R., J. Martinez-Alier and H. Correa, H., 2003. International capital versus local population: The environmental conflict of the Tambogrande mining project, Peru. Society \& Natural Resources, 16, 775-792.

Pérez-Rincón, M.A., 2006. Colombian international trade from a physical perspective: Towards an ecological "Prebisch thesis". Ecological Economics, 59, 519-529.

Quiroga, R., 2005. Estadísticas del medio ambiente en América Latina y el Caribe : Avances y perspectivas. CEPAL Series Manuales. United Nations. Economic Commission for Latin America and the Caribbean. Division of Statistics and Quantitative Analysis. Santiago de Chile.

Repetto, R., 1989. Wasting assets: natural resources in the national income accounts. World Resources Institute. Washington, D.C.

Russi, D., A. C. Gonzalez-Martinez, J. Silva-Macher, S. Giljum, J. Martinez-Alier and C. Vallejo (forthcoming). Material flows in Latin America: A comparative analysis of Chile, Ecuador, Mexico and Peru. Journal of Industrial Ecology.

Sachs, J. D. and A. M. Warner, 1999. The big push, natural resource booms and growth. Journal of Development Economics, 59, 43-76.

SENER, 2007. Sistema de información energética (SIE). Mexico. www.sie.energia.gob.mx

Stern, D.I., 2001. Progress on the environmental Kuznets curve? Environment and Development Economics, 3, 173-196

Stromberg, P., 2005. La industria maquiladora mexicana y el medio ambiente; una revisión de los problemas. In El medio ambiente y la maquila en México: un problema ineludible. (eds J. Carrillo \& C. Schatan), pp. 21-78. Colección Libros de la CEPAL, No.83. United Nations, México.

Székely, M., 2005. Pobreza y desigualdad en México entre 1950 y 2004 . El Trimestre Económico, LXXII (4), 913-931.

Ten Kate, A. and F. De Mateo, F., 1989. Apertura comercial y estructura de la protección en México: Estimaciones cuantitativas de los ochenta. Comercio Exterior, 39, 312-329.

Vallejo, M.C., 2006. La estructura biofísica de la economía ecuatoriana: el comercio exterior y los flujos ocultos del banano. Quito: FLACSO/Abya-Yala.

Weisz, H., F. Krausmann, C. Amann, N. Eisenmenger, K. H. Erb, K. Hubacek, 2006. The physical economy of the European Union: Cross-country comparison and determinants of material consumption. Ecological Economics, 58, 676-698.

World Bank, 2006. World development indicators. Washington DC. http://www.bancomundial.org/datos/datos pais.html 